\title{
Bringing Child-Friendly Village into Reality through Community Empowerment in Indonesia
}

\author{
Eva Agustinawati \\ Department Development Extension /Community Empowerment Study Program \\ Postgraduate Program of Sebelas Maret University, Surakarta, Indonesia.

\section{Ravik Karsidi} \\ Department Development Extension /Community Empowerment Study Program \\ Postgraduate Program of Sebelas Maret University, Surakarta, Indonesia.

\section{Drajat Tri Kartono} \\ Department Development Extension /Community Empowerment Study Program \\ Postgraduate Program of Sebelas Maret University, Surakarta, Indonesia.
}

\author{
Kusnandar \\ Department Development Extension /Community Empowerment Study Program \\ Postgraduate Program of Sebelas Maret University, Surakarta, Indonesia.
}

\begin{abstract}
The problem befalling child appears more frequently in many social media with a very variety of complex causes and effects. Government issued child-friendly city policy in some regions called child-friendly village. Public participation is needed for implementing program through community empowerment. This research aimed to find out how child-friendly city can be brought into reality through community empowerment in Indonesia. This research employed Grounded Theory approach with purposive sampling and snowball sampling being the sampling techniques. Data analysis was conducted using domain analysis, taxonomic analysis, componential analysis, and discovering cultural themes. The result of research showed that childfriendly village program was initiated by people from idea, planning, implementing to monitoring and evaluating. This program was helped by PT. Sari Husada through CSR (Corporate Social Responsibility) and successfully brought child-friendly village into reality.
\end{abstract}

Keywords: child, empowerment, community

\section{INTRODUCTION}

Individual are categorized into children when they are below 18 year age, including those still in their mothers' womb. Child is a part of citizen entitled to benefit from development process. Child problems in Indonesia increase quantitatively. Violence, negligence, child worker, trafficking, and now the more hazardous one, terrorism cases have affected child. Children still under their parents' caretaking will be "poisoned" easily with terrorism. These children are in endangering condition and need protection from the State.

Article 28b clause (2) of the 1945 Constitution (Undang-Undang Dasar 1945) states that every child shall have the right to live, to grow and to develop, and shall have the right to protection from violence and discrimination". Similarly, Article 34 mentions that "Impoverished persons 
and abandoned children shall be taken care of by the State". Those articles indicate that every child living Indonesia is under the State's responsibility and no child should live abandoned.

One of policies issued by government as the attempt of accelerating the child protecting effort is Child-Friendly City (CFC) program. CFC program was originally based on Law No.23 of 2002 that was then amended with Law Number 35 of 2014 about Women Empowerment and Child Protection No.2 of 2009. Meanwhile, guideline of CFC development at province level has been governed in Minister of Women Empowerment and Child Protection's Regulation Number 13 of 2010. The realization of CFC program requires support from many parties including (national and local) legislative institution, judicative institution, and governments from central to village/kelurahan levels. Those involved in this program are business (company), academician and most importantly, community including individuals, children, adults, and families (Rosalin, 2011). The policy organized by bureaucratic apparatuses in practice should involve participation through community empowerment. CFC policy has not involved community's active participation completely. Government still focuses on the program implemented by the service for CFC implementation. People are still on level of uncaring about the implementation of CFC. Many problems ignoring the right of child occur at community level. This study will consider how to bring CFC or Child-Friendly City into reality through community empowerment.

\section{METHOD}

This research was taken place in Yogyakarta formerly called "Kampung Preman (Village of hoodlums) and now becoming child-friendly village. This research was conducted in Badran Village, particularly in RW 11 located in the western part of Yogyakarta city adjacent directly to one of big rivers crossing, Winongo River. The approach employed was Grounded Theory, the expansion of inductive theory from the data available to explain a social phenomenon (Sarosa, 2012). Data source of research consisted of two: primary and secondary data. Primary data was community including elders and children in Badran Village and RT/RW (neighborhood) administrators. Secondary data consisted of document and archive.

The sampling techniques employed were purposive sampling and snowball sampling ones. Purposive sampling is the sampling technique with certain consideration, in which the informants are considered as most knowledgeable about what expected, such as RW administrators and community leaders of Badran village. Meanwhile, snowball sampling is the technique of sampling data source originally small in number to the large one (Sugiyono, 2013). An informant became key informant, RW administrator, who would designate other informants according to the author's need. Data collection was carried out using interactive method including in-depth interview, participatory observation, and Focus Group Discussion (FGD). Meanwhile, non-interactive method included questionnaire, document or archive recording, and participatory observation.

Data validation was carried out using source triangulation in which, according to Patton in Sutopo (2006), the author employed varying data sources, meaning the same or similar data will be more valid when it was extracted from some different sources. Data analysis was carried out using domain analysis, taxonomic analysis, componential analysis, discovering cultural themes.

\section{RESULT AND DISCUSSION}

The main idea about friendly-child city has been developed during the $2^{\text {nd }}$ UN's Conference on human settlement (2nd HABITAT) held in Istanbul in 1996. Child-Friendly City is based on four principles: (1) fair treatment for everyone, regardless ethnic, sex, religion, and social-economic 
background, (2) the child's best interest becomes priority, (3) the right of children to better life and development, (4) respecting the right of children (Nour, 2013).

Children protection is any activity conducted to ensure and to protect children and to fulfill their rights in order to live, grow, develop, and participate optimally according to humanity dignity and prestige, and be protected from violence and discrimination. Child-Friendly City (CFC) is regency/city's development system integrating government's commitment and resource, comprehensively and sustainably planned business realm into development policy, program and activity, and development intervention in the form of development policy, program and activity to fulfill the right of children. The objective of CFC is to build regency/city's government leading to the attempt of transforming the Convention of the Right of the Child from legal framework into definition, strategy, and intervention of development in the form of development policy, program, and activity in the attempt of fulfilling the right of the child in a regency/city area dimension (Rosalin, 2011).

Child-Friendly City generally has an objective to ensure the children's right to access basic quality service through sustainable development (Rismanchian, 2007). Government and nongovernment institutions intervene in the problem of child aiming to build many parties' response. It particularly pertains to the problem of child related to social issues such as street children, children with legal problem, and many more problems occurring around community (Onwong, 2015).

Child-Friendly City is constructed to ensure that children have an opportunity of growing with potency they have. Another opportunity equally important is that of accessing resources they need. Family, community, and other institutions such as school, healthcare institution, and other protection institution contribute to CFC. They become partners and serve to uphold the right of the child in urban life.

CFC development can be conducted using several approaches: firstly top-down system in which idea, program and implementation, as well as evaluation are conducted from government and then going down to community. Secondly, it is bottom-up approach, the idea and program of which comes from community. Thirdly, it is the combination of both of them in which community has had an idea to realize CFC supported by government requiring location to develop CFC. Community's responsibility is a unity that should be implemented in balance so that the process of protecting the right of child will be realized immediately.

Yogyakarta City welcome Child-Friendly City program by calling it Child-Friendly Village. Child-Friendly Village is neighborhood (RW)-based development, unifying local commitment and resource, community and business realm existing in local environment in the attempt of respecting, ensuring, and fulfilling the right of the child, protecting children from violence, exploitation, sexual abuse, and discrimination, and listening to child's opinion, planned consciously, comprehensively, and sustainably (Pemerintah Kota Yogyakarta,2013).

Community is a group of people interacting with each other continuously so that there is a patterned and organized social relation. Community attempts to meet the need and to solve social problem, leading to life process and changing effort to occur continuously (Sutomo, 2011). Community becomes the main actor in utilizing its surrounding environment to achieve the sustainable development. This activity is the manifestation of process called community empowerment. Community empowerment is related to sustainable development that will bring community into a sustainable economic, social, and ecological development. 
Community empowerment is defined as the attempt of fulfilling individual's, group's, and public's needs in order to have ability of choosing and control environment to meet any wishes including accessibility to resource related to occupation and social activity. The main elements of community empowerment are community authorization and capacity development. To get authority and capacity in managing development, community should be empowered through empowerment process (Sutomo, 2011).

Community empowerment is a process aiming to make the community independent in order to improve their standard of life by using and accessing local resource as well as possible. This community empowerment process put people to be main party or the center of development (people or community-centered development) (Delivery team in Mardikanto, 2014).

Community empowerment is generally the process of empowering a group existing in community both economically and socially. Empowering process enables the community to analyze and to deal with the problems they encounter, to meet their life need and to live independently.

The goals of community empowerment are: (1) improved institution: it is expected that through improving activity/action the needs of institution can be met, (2) improved business: the improvement of accessibility and institution can improve the business ran, (3) improved income: the improved business can improve income including family's and community's incomes, (4) improved environment: improved income is expected to improve (physical and social) environment because environment damage is often due to poverty, (5) improved life: good income and environment condition are expected to improve life condition of family and community, (6) improved community: better life condition supported with better (physical and social) environment is expected to realize the better community life (Mardikanto, 2011).

In empowering process, it is community that becomes the actor to define development. Community (people) is told to study and to analyze need, problem encountered and opportunity of dealing with the problem. In addition, community can identify the problem easily and appropriately, and can access resource internally and externally.

So many cases affecting children such as child exploitation, child trafficking, child worker and other unrevealed cases will affect the quality of children. Those cases will end up with the negligence of children's rights that should be the state and community's responsibility. The problems of children occurring within community lead to a consciousness that children are on marginalized position. Children have distinctive problem that should be solved by all elements, including community. Children are a part of community requiring distinctive management by both government and community. Children can be not only the object of empowerment conducted by community but also the object of empowerment process.

In 1970s, Badran Village in Yogyakarta was known as kampong preman becoming the heavy burden for those living in it. This stigma also affected children's psychology. Label of hoodlum's offspring or anak preman became a negative stigma for children. Considering this condition, people of Badran Village began to try to get out of such condition. In 2010, people of Badran Village started to establish a forum called "children-friendly village". They involve children, early age child education cadre, integrated service post cadre, community leader, religion leader and local government apparatus. This forum activity initially identified the problems arising around the village, particularly the ones affecting children. It is community that understands what becoming the source of problem and how to get out of the problem. The 
people's agreement to change hoodlum village into child-friendly village focuses more on nonphysical children development.

In this stage, empowerment process starts with involving social process and action in which the members of a community organize themselves in planning and taking collective action to solve social problem or to meet social needs according to their own ability and resource (Suharto, 2010). Empowerment as a process is an activity of reinforcing and or optimizing the powerfulness (in the sense of competitive ability and or advantage) of weak group within community, including individuals having problems. Community empowerment is a process in which community, particularly those with limited resource, women, children, and other marginalized groups, is supported in order to improve their wellbeing and to be independent.

Most of Badran villagers live in Winongo River bank with entrepreneur being their livelihood and with lower-middle economic class. A variety of businesses flourish in the village, such as bakpia, yangko, and onde-onde sellers. Fish breeding is also promoted using karamba (basket put in a stream for raising fish) system in the river around the village. Save-loan cooperatives with members of society being the members flourish in Badran Village neighborhood. Meanwhile, the activity that can be a model to surrounding neighborhood is rubbish bank. People collect domestic rubbish once a week to be exchanged with money saved in one of administrators that can be withdrawn later in certain period of time.

The characteristics of people with any problems and activities become a capital to bring childfriendly village into reality in community empowerment. Badran Village is an urban area located along Winongo River and in black area. Viewed from education, social, economic and health aspect, this village still highly needs to be empowered to remove negative stigma and to change it into a more productive and child-friendly village. Community and religion leaders' commitment becomes the main capital in establishing child-friendly village. The key to community empowerment process lies on the community and its leaders. Such the process can be called top-down process, the one arising from community level.

The appearance of cadres within community in education and health sectors become a capital of community empowerment as well. They are the starting point of any activity aiming to make a village child-friendly. Cadres fight for making the children' right to education and health fulfilled without reasonable return to their work. The existence of health cadre supports integrated service post (posyandu) program conducted once a month to monitor the health of children, particularly under-five age children. Meanwhile education cadre focuses more on promoting Early Age Child Education (PAUD) held routinely in Badran Village.

Community activity the Badran Village has had becomes a capital in community empowerment process to make it a child-friendly village. Community leaders along with the community with any social-economic activities and cadres struggling in health and education sector have been able to change the mindset of hoodlum village into child-friendly village. Another party playing equally important is PT. Sari Husada Yogyakarta with its CSR (Corporate Social Responsibility) program. This program is the result of collaboration between PT. Sari Husada and PKPU (Pos Keadilan Peduli Umat or in English "Justice Post Caring about Religious Community"). So, the implementation of CSR by PT. Sari Husada was not conducted directly by the company but delegated to third party, PKPU.

PT. Sari Husada's CSR program contributed to realizing child-friendly village by establishing rumah Srikandi (Srikandi House). Rumah Srikandi is intended (1) to improve the quality of nutrition for under-five age children, (2) to revitalize Early Age children Education institutions, 
and (3) to empower the women economically. To improve the quality of nutrition for underfive age children, Rumah Srikandi through empowering posyandu at RW (neighborhood) level can give mothers with under-five age children an independency in providing balance nutrition thereby mitigating the problems of malnutrition and nutrition deficiency. Through posyandu held in Rumah Srikandi, community particularly nutrition cadres are built and given knowledge about nutrition for child and under-five age child. Facilitator team from PKPU holds training and facilitation to local women in order to be nutrition cadres by giving them knowledge on exclusive breastfeeding, demonstrating how to cook food correctly to prevent the nutrition content from being lost. Cooking demonstration is also held by PKPU facilitator to enable the women to cook food varyingly, to prevent children from feeling bored with the food. In addition, through Rumah Srikandi, community is invited to plant vegetables and fruits in their house yard. It is intended to give the family the knowledge on healthy nutrition for baby and under-five age children. Another activity supporting under-five age children health program is a gathering to discuss how to deal with children with malnutrition and nutrition deficiency condition.

The empowerment in education sector is conducted by revitalizing Early Age Children Education (PAUD) institutions. The beginning step is taken by making the parents aware of enrolling their children in PAUD. PT. Sari Husada has also established a PAUD to facilitate the children to study in the school around the village. In addition, PAUD cadres are also authorized to manage and to develop PAUD.

To support the women empowerment program economically, PT. Sari Husada emphasizes more on reinforcing the capacity of community in cooperatives and micro-economic institutions. Productive business is also operated by developing batik craft, snack, and souvenir businesses. To meet the need for business capital, save-loan cooperatives begin to be developed. Another activity conducted for empowering the community in economic sector is the presence of rubbish bank.

During 2009-2014, Rumah Srikandi had been able to solve many problems in health, education, and economic sectors in Badran Village. At the same time, PT. Sari Husada provided some facilities such as funding and facilitator personnel corresponding to its core business. Rumah Srikandi successfully achieves the main objective to create independency and to empower the community. After PT. Sari Husada exited from the program, the community is expected to have been able to empower itself with program independency in inventorying problem, arranging program, implementing, and monitoring and evaluating the program. Child-friendly village program is a program resulting from Badran village community empowerment. This program still runs until today and to maintain the program, people should pay dues of IDR 500.00 (five hundreds rupiah) monthly as the substitute of operational cost.

Company should not only be responsible to shareholders and investor but also give answer to the question of people in which it operates and that of all community members. Corporate Social Responsibility aims to cater to community rather than serves to be a means of push the business forward financially (Kincaid, 2012). CSR conducted by company should hold on 3 principles: profit, people, and planet (Mardikanto, 2014). A perfect company not only seeks for profit but also cares about environment conservation (planet) and people's welfare (people). Company's mission and ethical code usually define initiative, form, strategy, and size of social responsibility. Those values are internalized into three ideas: moral, rational, and economic cases. Moral case is what the organization believes to be its obligation to the people (community); rational case attempted to work proactively to minimize the limitation of community (people) business by imposing it to the company; economic case aims to increase 
the financial value of company by maintaining its reputation among the stakeholders (Kincaid, 2012).

\section{CONCLUSION}

The problem of child increases quantitatively. That is why government has launched a program, Child-Friendly City (CFS) or child-friendly village. This program needs participation of many parties including community. Community that can identify the problem the children encounter and how to utilize the resource owned to solve the problem. This process is called community empowerment. Planning, implementation and evaluation and monitoring are all conducted by community (people). In addition to featuring the community empowerment process, child-friendly village program in practice is also supported by CSR (Corporate Social Responsibility. Partnership between community and company results in child-friendly village.

\section{References}

Kincaid, Matthew, 2012, Building Corporate Social Responsibility Through Servant-Leadership International Journal Of Leadership Studies, School Of Global Leadership \&Entrepreneurship, Regent University.

Nour,M, Hasan,E,O. 2013. Building Child Friendly Cities in the MENA Region, Springer Science+Business Media Dordrecht and UNESCO Institute for Lifelong Learning.

Mardikanto, T, 2011, Konsep-konsep Pemberdayaan Masyarakat, UNS Press, Surakarta 2014. Corporate Social Responsibility (Tanggunhgjawab Sosial Korporasi), Alfabeta, Bandung.

Onwong, M,C. 2015. The Effectiveness of Street Children Interventions in Eldoret, Kenya, International Journal of Science and Research (IJSR), Volume 4 Issue 9, September 2015,423-429.

Pemerintah Kota Yogyakarta, 2013, Petunjuk Teknis Kampung Ramah Anak (KRA), Yogyakarta.

Rismanchian, 0 and Rismanchian, A, 2007, Children participation in planning processes: the case of Child Friendly City project in post-earthquake Bam Iran, Urban Design International, Palgrave Macmillan, hlm. 143-154.

Rosalin, L, 2011, Kabupaten/Kota Layak Anak: (KLA) dalam Pengentasan Kemiskinan dan Perwujudan Hak Anak, Buletin Tata Ruang, Januari-Februari 2011, Jakarta.

Sarosa, S. 2012. Penelitian Kualitatif Dasar-dasar. Indeks, Jakarta

Soetomo, 2011, Pemberdayaan Masyarakat, Pustaka Pelajar, Yogyakarta

Sugiyono. 2013. Metode Penelitian Kuantitatif Kualitatif dan R\&D. Alfabeta, Bandung.

Suharto, Edi. 2010. CSR Dan Comdev Investasi Kreatif Perusahaan Di Era Globalisasi. Alfabeta, Bandung.

Sutopo, HB. 2006. Metodologi Penelitian Kualitatif. Surakarta: Sebelas Maret University Press, Surakarta.

Undang-undang Dasar Republik Indonesia (UURI) 1945

Republik Indonesia, 2002, Undang-Undang Republik Indonesia Nomor 23 Tahun 2002 Tentang Perlindungan Anak. Jakarta: Sekretaris Negara Republik Indonesia.

Unicef. 2009. Tahapan Pengembangan Kota Layak Anak, Jakarta 